\title{
Methods and devices for measuring metal cutting friction and wear
}

\author{
Metody i urządzenia \\ do pomiaru tarcia i zużycia w skrawaniu metali
}

WIT GRZESIK JOEL RECH *
DOI: https://doi.org/10.17814/mechanik.2019.2.16

\begin{abstract}
This paper presents different constructions of tribometers for determination of friction and tool wear developed in the cutting zone between the cutting tool and the workpiece materials. They are classified as the closed and open tribotesters. Relevant measuring techniques of various process outputs such as cutting forces, tool wear, cutting temperature and heat flux entering the contact surface of the rubbing element are outlined. Some limitations and practical applications are highlighted.
\end{abstract}

KEYWORDS: metal cutting, friction, wear, tribometer

W artykule zaprezentowano różne konstrukcje tribometrów do wyznaczania współczynnika tarcia i zużycia narzędzia w strefie skrawania - między narzędziem skrawającym i obrabianym materiałem. Urządzenia te sklasyfikowano jako zamknięte i otwarte tribotestery. Opisano odpowiednie techniki pomiarowe różnych wielkości wyjściowych procesu, takich jak: składowe siły skrawania, zużycie ostrza, temperatura skrawania oraz strumień ciepła wnikający do powierzchni kontaktu trących elementów. Wyjaśniono niektóre ograniczenia i podano praktyczne zastosowania tribometrów.

SŁOWA KLUCZOWE: skrawanie metali, tarcie, zużycie, tribometr

In metal cutting practice, the experimental and numerically-based investigations of the performance of the cutting process include intensive plastic deformation of the removed material and associated friction developed at the tool-chip contact surface. As a result, reliable friction and wear data are a key importance in the FEM modeling of the cutting process and different cutting operations. In general, the characterization of friction behavior in the secondary deformation zone (SDZ) i.e. at the tool-chip contact (the determination of the values of friction coefficient) is based on three different methods [1]:

- measurements of the components of the resultant cutting force using piezo- or strain-gauge dynamometers ( $1^{\text {st }}$ type); this very popular approach in the mechanics of metal cutting is described in Ref. [2];

- conventional tribometers (2 ${ }^{\text {nd }}$ type) which are typically used for testing the wear resistance of construction materials, as for instance hard alloy and bearing steels with special functional properties;

- specially-designed tribometers ( $3^{\text {rd }}$ type) which are better adapted for the mechanical, thermal and tribological conditions in the cutting zone.

* Prof. DSc Eng. Wit Grzesik (w.grzesik@po.opole.pl) - Technical University of Opole, Poland; Prof. DSc Eng. Joel Rech (joel.rech@enise.fr) - University of Lyon - ENISE, France
The first methods is usually used for the orthogonal cutting arrangement typical for turning and milling operations although is also tested in broaching operations [1]. During tribo-tests, normal and friction forces and contact temperature are continuously recorded and the local (also average) values of the friction coefficient. This methods does not consider the variations of the contact conditions [1] due to the changes of local sliding velocity, contact pressure and temperature. As a consequence, this approach ignore the presence of the sticking and sliding zone on the rake and flank faces. In order to overcome this situation, authors use either split tools or analytical models. In order to overcome these disadvantages it is propose to combine an interrupted turning with the deep analysis of the layer formation using several experimental techniques. The second and third methods which use both adapted or special tribometers are typically term the closed or open tribo-systems due to the fact that the refreshment of the contact specimen's (machined) surface is performed or not [1].

As mentioned above, in the second method conventional tribometers friction is quantified without surface refreshment different types of the cutting operations. The most commonly applied devices use the pin-on-disc or pin-on-ball arrangements. In particular, the disc (counterspecimen) is made of the work material, whereas the pin is made of the cutting tool material. In this case the both uncoated and coated substrate material similar as commercial cutting tool inserts can be employed. The second variant is frequently used to classify tool coatings in terms of their wear resistance or frictional behaviour.

In order to avoid special specimens in the form of pins commercial cutting tool inserts are often applied [3,4]. Unfortunately, such tribometers hardly provide relevant tribological conditions occurring along the tool-work material interface in the cutting process. However, the real contact between the sliding surface is modified by the wear products and, as a result, such friction data cannot be fully and sometimes are improved by appropriate numerical cutting simulations.

The third approach is developed based on special tribometers that simulate open tribo-conditions with different sliding velocity and contact pressure. One of the most popular configuration introduces a ball-ended pin which is placed just after a cutting tool during the machining of a tube's flat face [5].

At present, tribotesters are increasingly applied to surface engineering components since they have the potential for determining their functional properties (for instance to determine the wear resistance) as well for fundamental tribological characterization including cutting tools or indexable cutting tool inserts. 


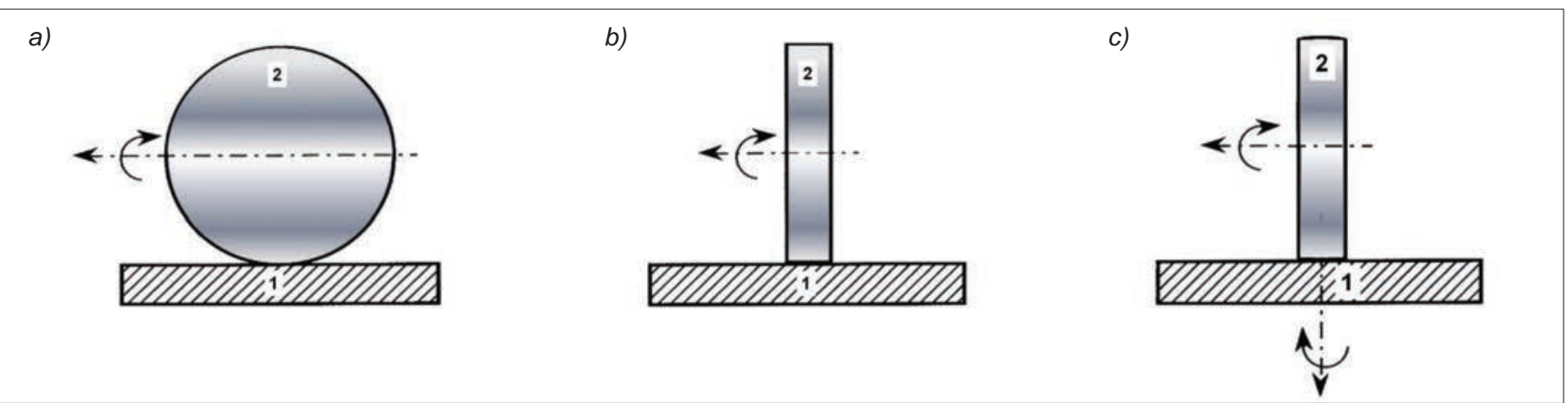

Fig. 1. Kinematic schemes of abrasion tests: a) spherical counterbody, b) cylindrical counterbody, $c$ ) domed cylindrical counterbody; 1 - specimen, 2 - counterbody [5]

Figure 1 presents kinematic schemes of three tribological tests with constant or variable tribological intensity. In case shown in Fig. 1a the spherical specimen is loaded against the flat surface of a much larger counterspecimen typically in the presence of abrasive particles. The modified version of this tester used for metal cutting application is shown in Fig. 2a. The progress of wear is usually determined by periodically interrupting the test and weighing the sample in order to assess the mass loss, and corresponding friction is continuously recorded as the output in the force measuring system (see also Fig. 2a). Other test methods which employ the same method are based on the use of a rotating cylindrical disc (Fig. 1b) or a rotating disc with a spherically domed rim, in combination with rotation of the specimen about an intersecting perpendicular axis (Fig. 1c). It should be noted that for the testers shown in Figs. $1 b$ and $1 c$ the tribological intensity and the worn area change during the test but the geometry of the wear scar is imposed by the test apparatus.

\section{Constructions of $2^{\text {nd }}$ type tribometers}

Three typical constructions of closed (adopted) tribometers are shown in Fig. 2. In case of the ball-on-disc tribotester shown in Fig. $2 a$ a hard sphere made of hardened bearing steel or sintered carbide is pressed with the load $F_{\mathrm{n}}$ against rotating specimen flat surface with the defined sliding track radius $r_{\text {track}}$. For the defined sliding speed $v_{\mathrm{s}}$ the tangential (friction) force $F_{\mathrm{t}}$ is measured and the friction coefficient is determined as the ratio $F_{t} / F_{n}$. During sliding friction tests also the evolution of the wear rate is observed based on the geometry of wear scars in the form of a characteristic spherical cap. This method is frequently used to test tribological behavior of deposited coatings with respect to the wear resistance and sliding friction.
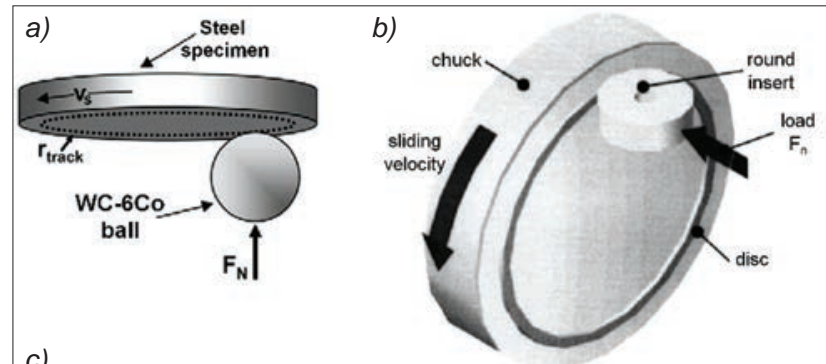

c)

d)
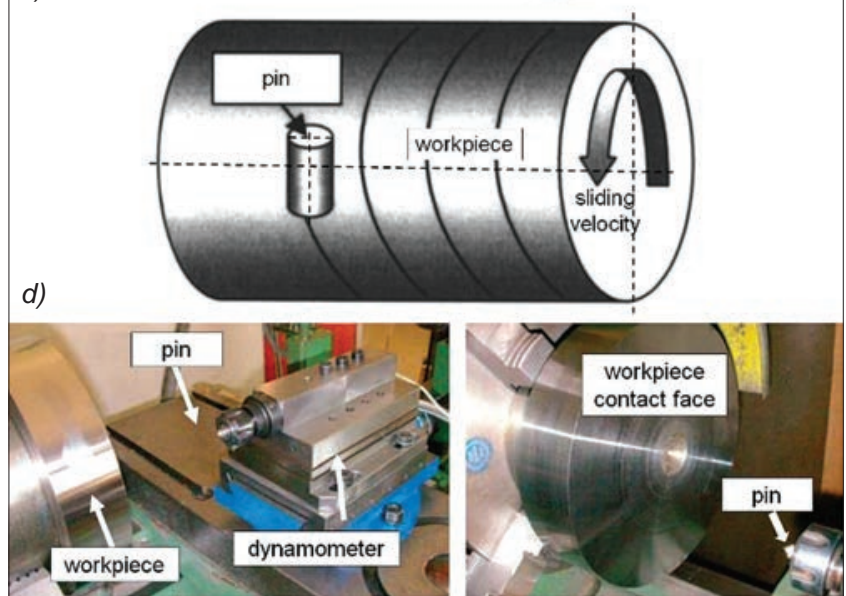

Fig. 2. Closed tribosystems - ball-on-disc (a), pin-on-disc (b) and pin-on-ring systems $(c)$ - and pin-on-disc tribometer integrated with piezoelectric measuring platform $(d)[1,3,5-9]$

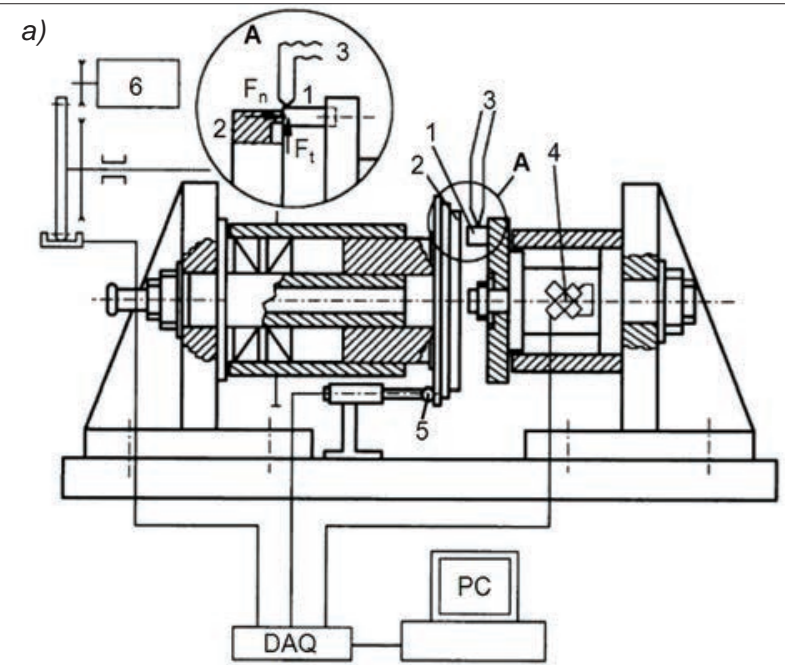

1 - pin, 2 -disc, 3-K-type thermocouple, 4-dynamometer, 5 - inductive sensor, 6 - motor with stepless speed control b)

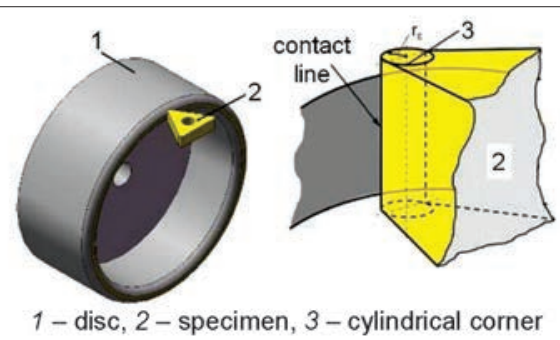

c)

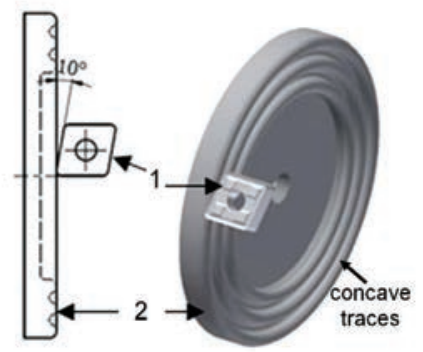

1 -specimen (insert), 2 - profiled disc
Fig. 3. A scheme of the cylinder-on-disc tribotemeter shown in Fig. $2 b$ with the load and temperature control systems (a); location of the cutting insert against the sliding trace of the $\operatorname{disc}(b, c)[3,6,10]$ 

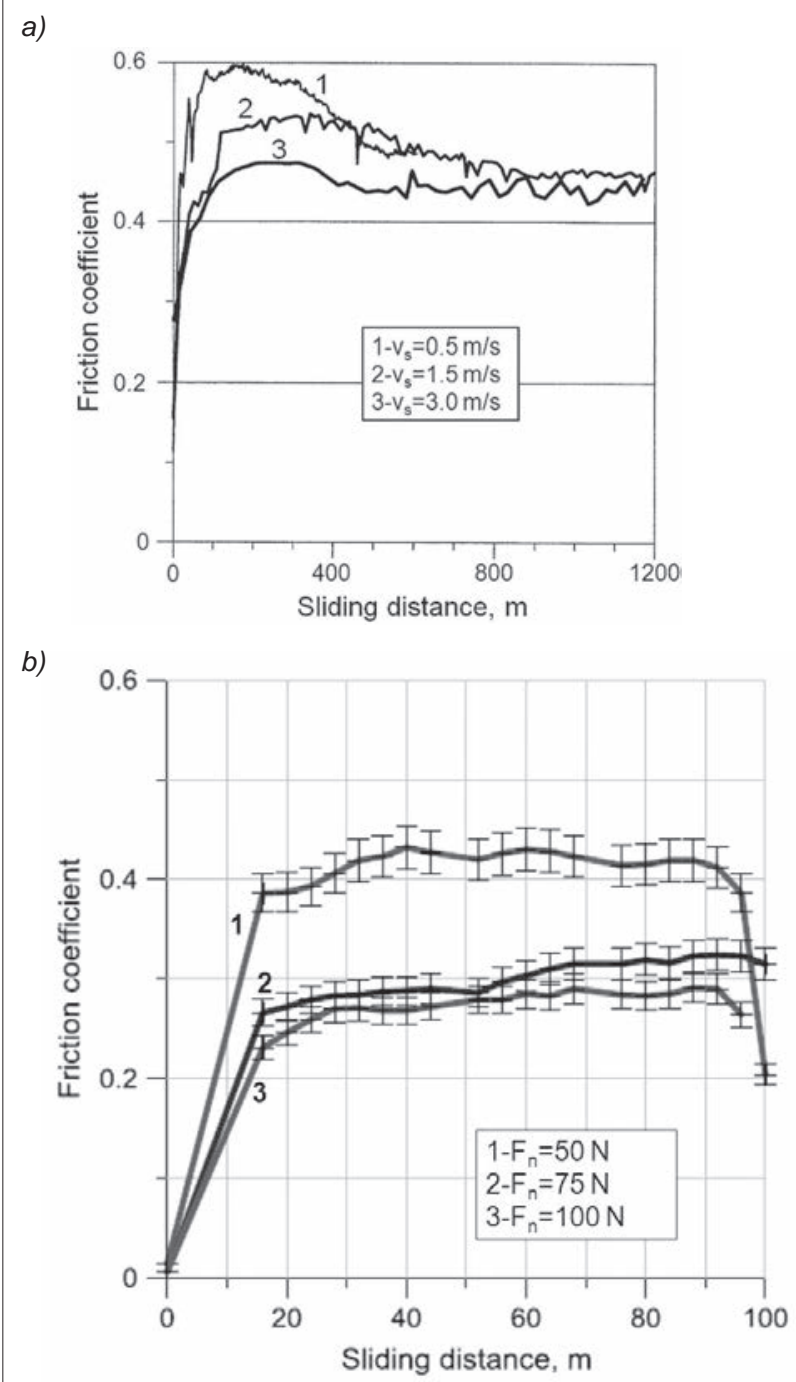

c)

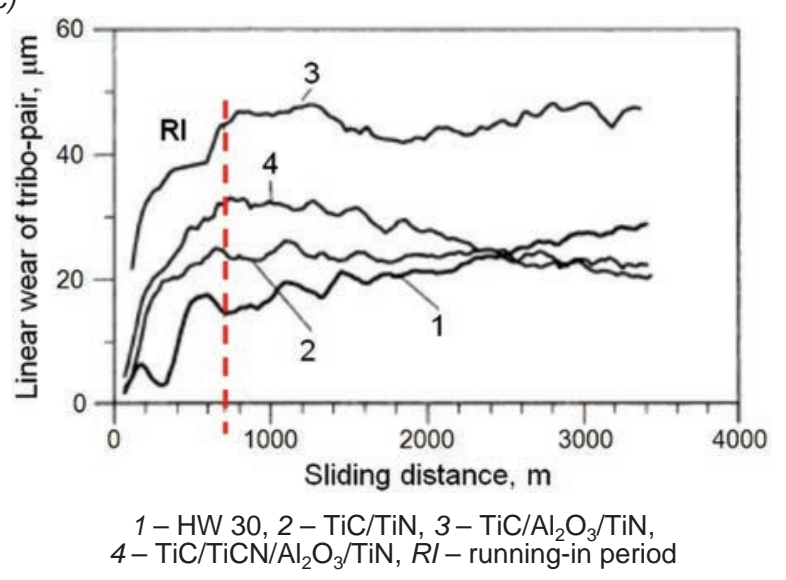

Fig. 4. Examples of records showing changes of the friction coefficient fo $\mathrm{TiC} / \mathrm{TiCN} / \mathrm{Al}_{2} \mathrm{O}_{3} / \mathrm{TiN}$ coated carbide- AISI 1045 steel for variable sliding velocity (a) [3], and $\mathrm{Si}_{3} \mathrm{~N}_{4}$ ceramic-SCl (spheroidal cast iron) tribo-pair for variable normal load $(b)$ [4], and relative linear wear of the tribo-pairs (c) recorded for the sliding speed of $3 \mathrm{~m} / \mathrm{s}$

In case of pin-on-disc method the specimen is made in the form of thin pin which is localized perpendicular or tangential to the flat disc surface (as in Fig. $2 b$ ). When commercial cutting tool inserts are tested special pin is replaced by the cylindrical corner of the insert as shown in Fig. $4 a$. The sliding track is a narrow flat or concave cog (also a series of cogs as in Fig. 3c). In real tests a rounded insert of 1 in. diameter was used and the maximum (Hertzian) contact normal stresses are estimated at the level of
1.2 GPa [6]. This method is effectively used to determine the friction coefficient values for variable load and sliding velocity as shown in Fig. $4 b$. The scheme of the modified pin-on-ring tester is shown in Fig. 3c. The countermaterial is mounted as the workpiece in the chuck in the lathe and the pin in the tool holder integrated with the dynamometer as shown in Figs. $2 d$ and $3 b$. A spring-loading system is utilized to apply the normal force. Wear testing with the continuous introduction of fresh, unworn ring material can be performed using the feed drive of the lathe.

The functional structure of the pin-on-disc tribotester used in testing PVD-TiAIN, TiC/TiN, TiC/Al $\mathrm{O}_{3} / \mathrm{TiN}$ coated carbide pins in conjunction with a 18-8 corrosion resistant steel, a carbon $\mathrm{C} 45$ steel and flake cast iron is shown in Fig. 2a (the model of this apparatus is shown in Fig. $2 b$ ). During the tribo-tests the friction force, the contact temperature and the linear displacement of the specimen are continuously recorded by means of an inductive sensor and K-type thermocouple, and the signals are processed in a real-time mode. As a result, the evolution of the friction coefficient calculated as $\mu=F_{\mathrm{t}} / F_{\mathrm{n}}$ (as shown in Fig. $4 a$ and $b$ ) and a couple linear wear measured by means of an inductive sensor shown in Fig. 3a (Fig. 4c) are recorded.

\section{Constructions of $3^{\text {rd }}$ type tribometers}

A group of some popular constructions of open tribometers are shown in Fig. 5. The difference between closed and open variants (Fig. $2 b$ versus Fig. $5 a$ ) is that the cutting tool creates a fresh surface in the front of the pin. Moreover, oxidation of the fresh surface produced in each rotation of the workpiece is minimized by mounting a small chamber with argon gas flowing at the high rate which protects the sliding contact. In order to avoid the cutting action of the pin, its end surface has a small chamfer inclined at the negative rake of $80^{\circ}$. The friction force is measured by strain gauges similar to the apparatus presented in Fig. 3a. The final conclusion from wear mechanisms observed [11] is that the modified pin-on-disc tester reproduces satisfactorily the contact conditions and simulates successfully cutting tool wear.

Is well known that in a real cutting process, as shown in Fig. 6 , the sliding velocity varies along the tool-workmaterial contact, the friction coefficient and the heat partition coefficient vary also along the contact in the case of steel and stainless steel machining [12]. Moreover, the contact pressure, along the tool rake face of a cutting tool, varies considerably. For instance, its maximum value is close to the cutting edge and easily reaches $3.5 \mathrm{GPa}$ for Inconel cutting as documented in Ref. [16]. For this reason the cutting tool is replaced by a pin having a spherical geometry. The application of an open tribometer shown in Fig. $4 \mathrm{C}$ and the experimental procedure illustrated in Fig. 6a allow to explain the evolution of apparent friction coefficient and of the adhesive friction coefficient versus sliding velocity. In addition, the thermal effects are considered by means of thermistor and the heat flux entering the coated pin end was predicted. It has been revealed that friction coefficient decreases with sliding velocity and contact pressure.

Another approach is the modified pin-on-ring systems, where a pin rubs over a cylindrical surface in a helical movement. In this case the oxidation of the contact surface cannot be avoid. Consequently, an in-process method based on the orthogonal cutting arrangement is proposed as shown in Fig. $5 e$.

In the real set-up shown in Fig. $8 a$ the tribometer consists of a spring preloaded tungsten carbide pin with 


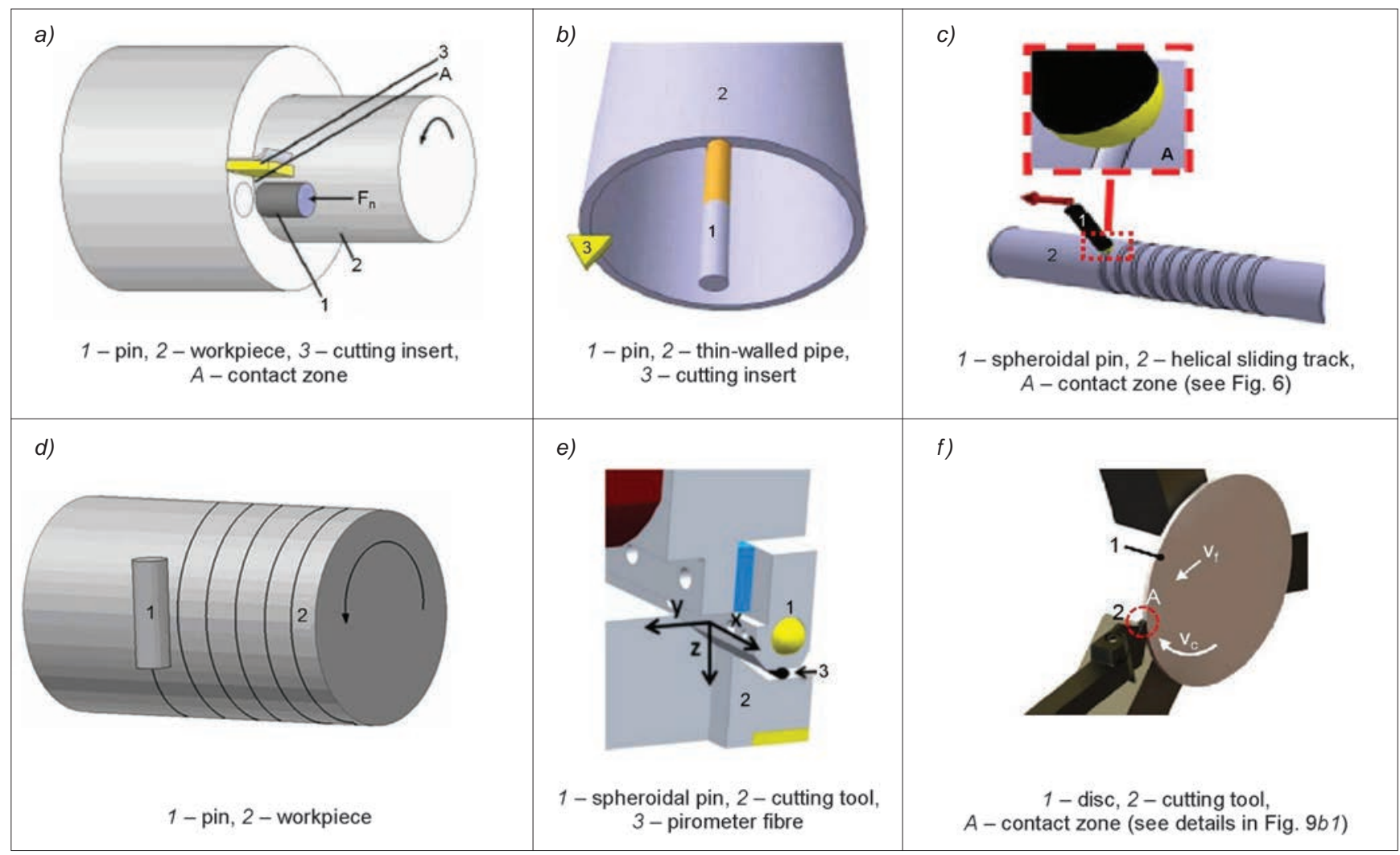

Fig. 5. Schemes of open tribometers of the $3^{\text {rd }}$ type developed to characterize friction in cutting: $a$ ) $-b$ ) modified pin-on-disc methods using flat-ended pins $[1,11], c)$ pin-on-disc method using ball-ended pin [12], d) pin-on-ring method using cylindrical pin [13], e) in-process tribometer with ball-ended pin [14], f) in-process friction test $[1,2,15]$

a $3 \mathrm{~mm}$ spherical tip mounted behind the cutting edge and rubbing on the freshly generated work piece surface. In order to minimize the reactions with air, the distance between the cutting edge and pin is kept as low as possible. The pin is placed $14 \mathrm{~mm}$ behind the orthogonal cutting contact zone to ensure the time interval between the surface generation by the cutting tool and the measurement of the friction coefficient as low as possible. Before the machining test he pin is preload $F_{\mathrm{n}}$ by a spring, which corresponds to the feed force at same cutting conditions. The friction force $F_{\mathrm{t}}$ on the pin are measured by a 3D-piezoelectric dynamometer. Finally, taking into account the force resolution shown in Fig. $5 e$, the friction coefficient is estimated as the ratio $F_{\mathrm{t}} / F_{\mathrm{n}}$. The changes of the friction coefficient resulting from variable cutting (sliding) speed for the TiAIN+TiN coated pin sliding against various steels and titanium alloys are presented in Fig. $8 b$.

The concept of the friction test presented in Fig. $5 f$ is also derived from an orthogonal cutting process but its originality results from a high material deformation and friction process by using an extremely negative rake angle. As should be expected large rake angle suppresses the formation of chips and results in a smooth plastic flow of metal over the tool surface. As a result, very high contact temperatures are generated resulting in an intensive thermal softening which approach the thermal conditions occurring in metal cutting processes. The concept was examined for AISI 1045 and AISI 4140 steels and Inconel 718 in combination with uncoated WC-6Co cemented carbide tools. The localization of the cutting tool insert against the thin disc made of the workpiece material sliding with the velocity $v_{\text {rel }}$ is shown in Fig. $9 a$. The test was performed on a broaching vertical machine. Surface temperature was measured by a two color fibre pyrometer. Similarly as in previous orthogonal test the friction coefficient expresses the ratio $F_{\mathrm{t}} / F_{\mathrm{n}}$. Figure $9 b$ shows the records of the measured forces, temperature and the friction coefficient for a relative velocity of $100 \mathrm{~m} / \mathrm{min}$. Due to substantial differences between measured and predicted contact temperature, the friction model was calibrated and evaluated by numerical post-processing based on the experimental results [17].

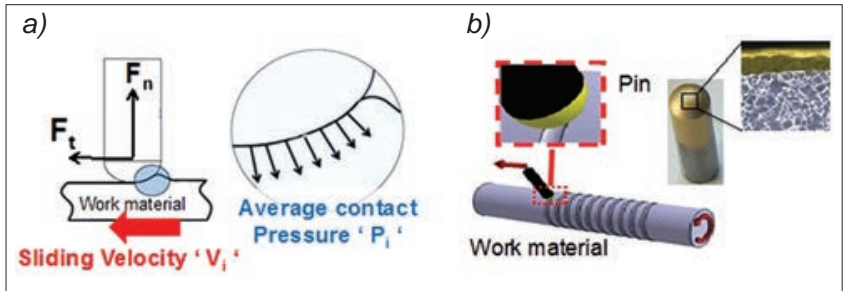

Fig. 6. Contact and kinematic conditions in tribo-tests (a) using coated ball-ended pin $(b)$ from Fig. $5 c[12,16]$

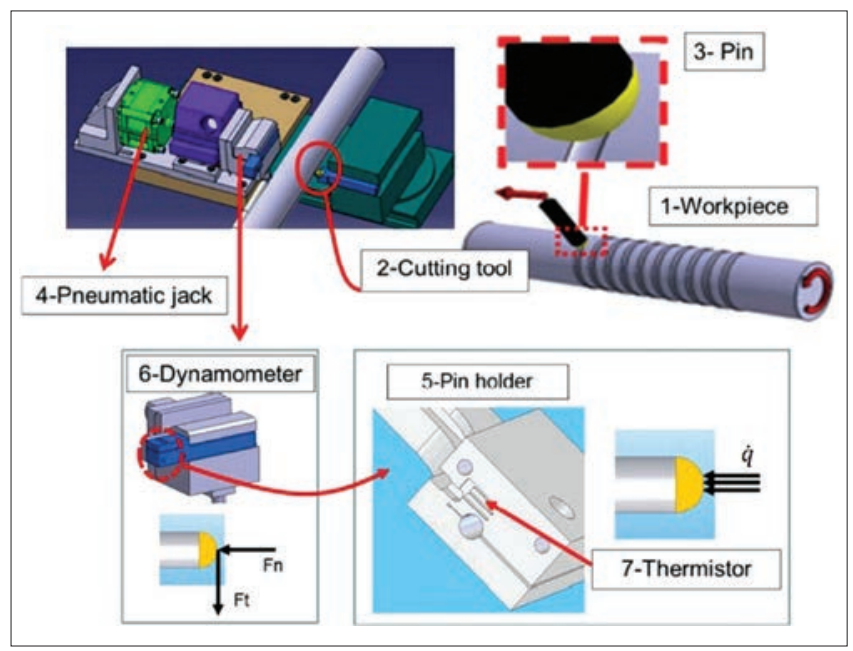

Fig. 7. Functional elements of the open tribometer pin-on-ring from Fig. $5 c[11,12]$ 


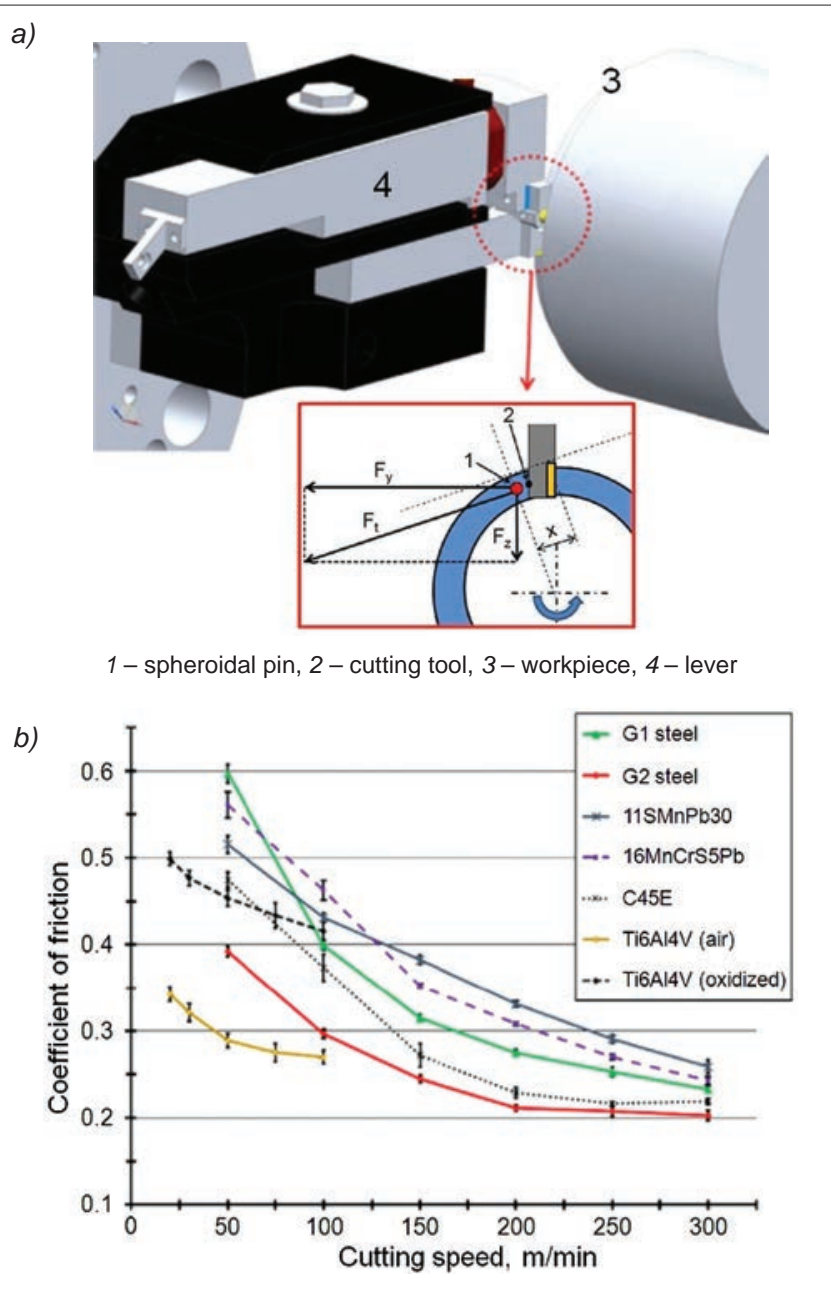

Fig. 8. Construction details of tribotester based on the scheme shown in Fig. $5 e$ with force resolution (a), and changes of the friction coefficient $(b)$ for different cutting speeds and machined materials $[1,2,14]$

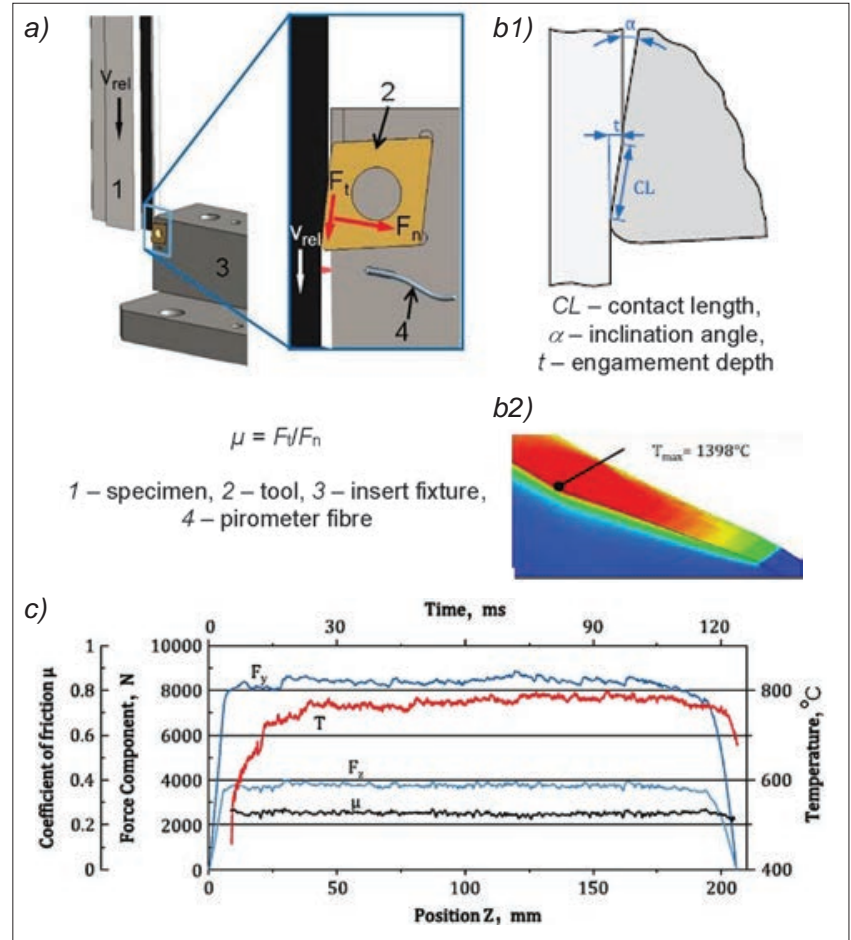

Fig. 9. Construction details of tribotester based on the scheme shown in Fig. $4 e(a)$, details of the tribo-contact (b1), temperature distribution (b2) and changes of measured forces and resulting friction coefficient for selected record $(c)$ (test conditions: work material - AISI 1045 steel, cutting insert $-\mathrm{H} 13 \mathrm{~A}$ carbide, $t=1 \mathrm{~mm}, a=10^{\circ}, v_{\mathrm{rel}}=100 \mathrm{~m} / \mathrm{min}$ ) [15]

\section{Summary}

In fact, it is not possible to obtain fully reliable friction data for metal cutting processes due to very complex interactions existing in the cutting zone and especially in the secondary deformation zone when coupling the rake surface of the tool and the fresh surface of the chip. For machining experiments a few typical tribotesters which utilize different measurement technique are designed. In general, their functionality is based on closed and open tribosystems, i.e. three groups are distinguished. The most valuable seems to be tribometers (tribotesters) from the $3^{\text {rd }}$ group which better reproduce the tribological conditions producing in the secondary cutting zone due to refreshing of the contact (machined) surface. In order to achieve the closed similarity of the friction data obtained directly from the cutting process and tribotests also the cutting pressure and cutting temperature are controlled. In general, some analytical and simulation post-treatment methods are necessary in order to improve the prediction accuracy.

\section{LITERATURE}

1. Melkote S., Grzesik W., Outeiro J., Rech J., Schulze V., Attia H., Arrazoal P.J., M'Saoubi R., Saldana Ch. "Advances in material and friction data for model ling of metal machining". CIRP Annals - Manufacturing Technology. 66, 2 (2017): pp. 731-754.

2. Grzesik W. "Advanced machining processes of metallic materials". Amsterdam: Elsevier, 2017.

3. Grzesik W., Zalisz Z., Niesłony P. "Friction and wear testing of multilayer coatings on carbide substrates for dry machining applications". Surface and Coatings Technology. 155 (2002): pp. 37-45.

4. Grzesik W., Rech J., Żak K. "Determination of friction in metal cutting with tool wear and flank face effects". Wear. 317 (2017): pp. 8-16.

5. Hutchings I.M. "Abrasive and erosive wear tests for thin coatings: a unified approach". Tribology International. 31 (1998): pp. 5-15.

6. Grzesik W., Zalisz Z., Król S., Niesłony P. "Investigations of friction and wear mechanisms of the PVD-TiAIN coated carbide in dry sliding against steels and cast iron". Wear. 261 (2006): pp. 1191-1200.

7. Adamczak S., Świderski J., Dobrowolski T. "The assessment of the surface texture friction node components after tribological tests". Mechanik. 12 (2017): pp. 1144-1147.

8. Hedenquist P., Olsson M. "Sliding wear testing of coated cutting tool materials". Tribology International. 24 (1991): pp. 143-150.

9. Ozlu E., Budak E., Molinari A. "Analytical and experimental investigation of rake contact and friction behavior in metal cutting". Int. J. Machine Tool and Manufacture. 49 (2009): pp. 865-875.

10. Bogdan-Chudy M., Niesłony P. „Ocena warunków tribologicznych podczas skrawania stopu Inconel 718 płytką z węglika spiekanego". Mechanik. 8-9 (2015): pp. 91-97.

11. Rech J., Claudin C., Grzesik W., Zalisz Z. "Characterization of the friction properties of various coatings at the tool-chip-workpiece interfaces in dry machining of AISI 4140 steel". Proc. IMechE Part J: J. Engineering Tribology. 222 (2008): pp. 617-627.

12. Zemzemi F., Rech J., Ben Salem W., Dogui A., Kapsa Ph. "Identification of friction and heat partition model at the tool-chip-workpiece interfaces in dry cutting of an Inconel 718 alloy with cbn and coated carbide tools". Advances in Manufacturing Science and Technology. 38 (2014): pp. 5-21.

13. Olsson M., Söderberg S., Jacobsson S., Hogmark S. "Simulation of cutting tool wear by a modified pin-on-disc test". Int. J. Machine Tool and Manufacture. 29 (1989): pp. 377-390.

14. Smolenicki D., Boos J., Kuster F., Roelofs H., Wyen C.F. "In-process measurement of friction coefficient in orthogonal cutting". CIRP Annals - Manufacturing Technology. 63 (2014): pp. 97-100.

15. Puls H., Klocke F., Lung D. "Experimental investigation on friction under metal cutting conditions". Wear. 310 (2014): pp. 63-71.

16. Zemzemi F., Rech J., Ben Salem W., Dogui A., Kapsa Ph. "Identification of a friction model at tool/chip/workpiece interfaces in dry machining of AIS14142 treated steels". Journal of Materials Processing Technology. 209 (2009): pp. 3978-3990.

17. Rech J., Claudin C., Polly P., Courbon C. "New aspects of metrology of frictional behaviour in metal cutting". Mechanik. 11 (2016): pp. 1751-1753. 